\title{
Hydrogen Peroxide and Cancer
}

\section{Paul TE Cusack*}

BScE, DULE, Saint John, Canada

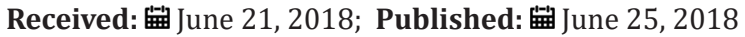

*Corresponding author: Paul TE Cusack, BScE, Paul TE Cusack, BScE, DULE, 23 Park Ave. Saint John, NB, E2J1R2, Canada

\section{Introduction}

I was asked to submit a minireview to this journal on oncology. I'll share an antidotal observation that may prove useful to cancer researchers. I studied hyper-ferritism and Ferric Chloride to see its possible link to schizophrenia. Those results are well published $[1,2]$. However, I noticed from that research a trend that 12 patients who should have had high hydrogen peroxide (H2O2) also universally had had some form of cancer in their medical history. I wonder if $\mathrm{H} 2 \mathrm{O} 2$ is not a carcinogen? Could the H2O2 break down that cell walls leading to cell mutation? I'm not an expert on cancer, nor do I intend to be, but perhaps this clue may lead to further research into to the causes of cancer. I provide here some possible chemical reactions that could take place in a system in balance. The cell walls are fatty acids $[3,4]$.

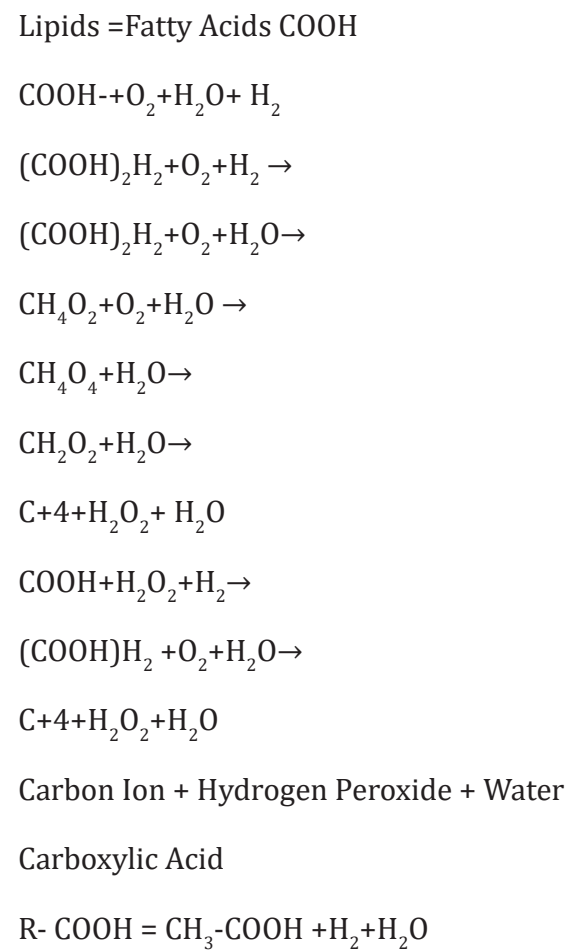

$$
\begin{aligned}
& \mathrm{CH}_{3}-\mathrm{COOH}+\mathrm{H}_{2}+\mathrm{H}_{2} \mathrm{O}+\mathrm{O}_{2}+\mathrm{Cl} \rightarrow \\
& 3 \mathrm{CH}_{2}-\mathrm{COOH}+2 \mathrm{H}_{2}+2 \mathrm{H}_{2} \mathrm{O}+2 \mathrm{O}_{2}+\mathrm{Cl}_{2} \rightarrow \\
& \mathrm{CH}_{3}+\mathrm{Cl}^{2} \rightarrow \text { Dichloromethane=Carcinogen }
\end{aligned}
$$

Animal studies have shown increases in liver and lung cancer and benign mammary gland tumors following the inhalation of methylene chloride (Figure 1).

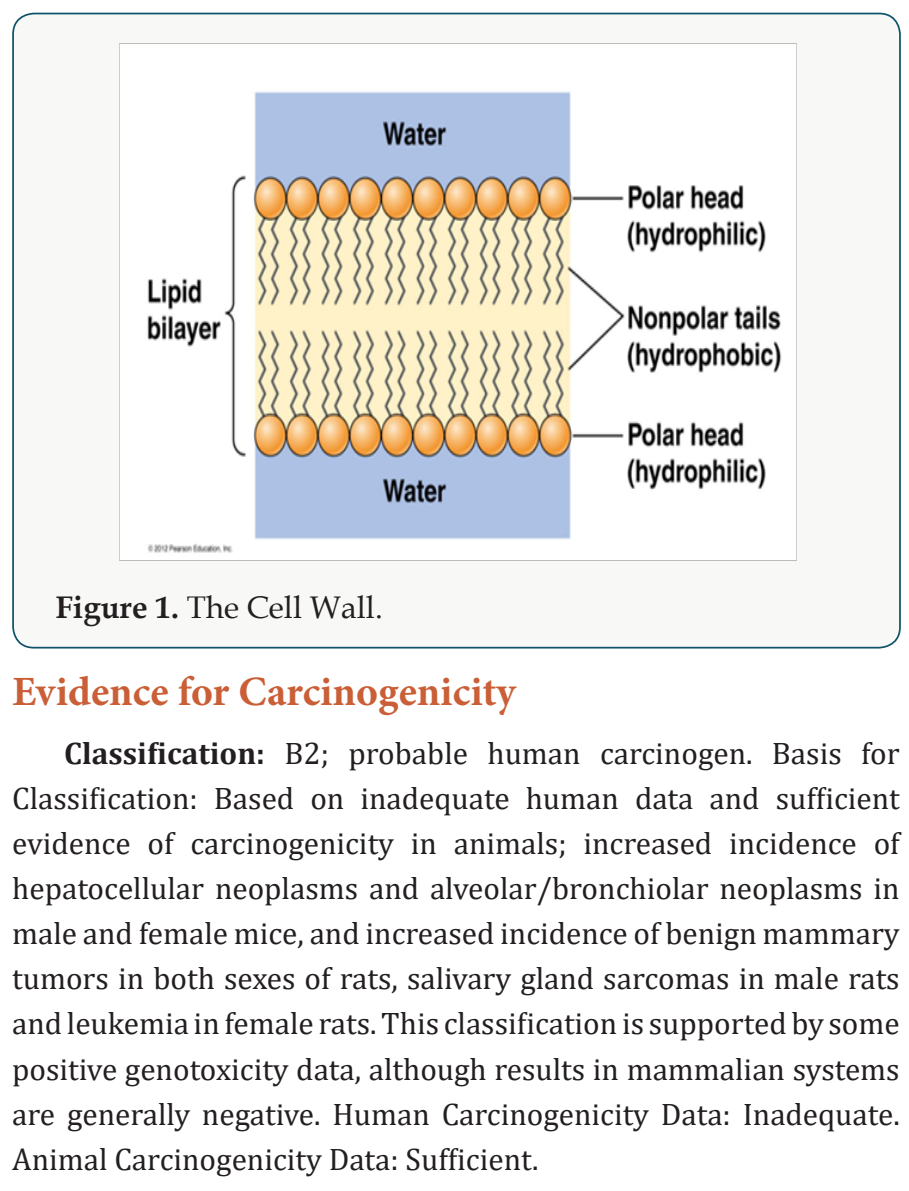




\section{Conclusion}

So we see that dichloride methane, a carcinogen, could be the culprit in allowing cancers (leukemia; Prostate; Breast; and lung cancers) to form. I reiterate; I'm not an expert in the field. I simply provide an observation that I hope is helpful to other researchers.

\section{References}

1. Cusack PTE (2012) Sz and Its Cause. LULU.
2. Paul TE Cusack (2018) Possible Cause of Schizophrenia: Ferric-chloride Disease. Archives of Endocrinology and Diabetes Care 1(1): 33-58.

3. Paul TE Cusack (2017) Dehydration: The Cause of Schizophrenia: Cholera; Ferric Chloride; and Caffeine. Ec Psychology and Psychiatry 6(2): 89-90.

4. Paul TE Cusack (2017) LSD, Caffeine and Cholera: Possible Causes of Schizophrenia. J Mol Genet Med 11(4): 296.
CC (1) This work is licensed under Creative

To Submit Your Article Click Here: Submit Article

DOI: $10.32474 /$ OAJOM.2018.02.000134

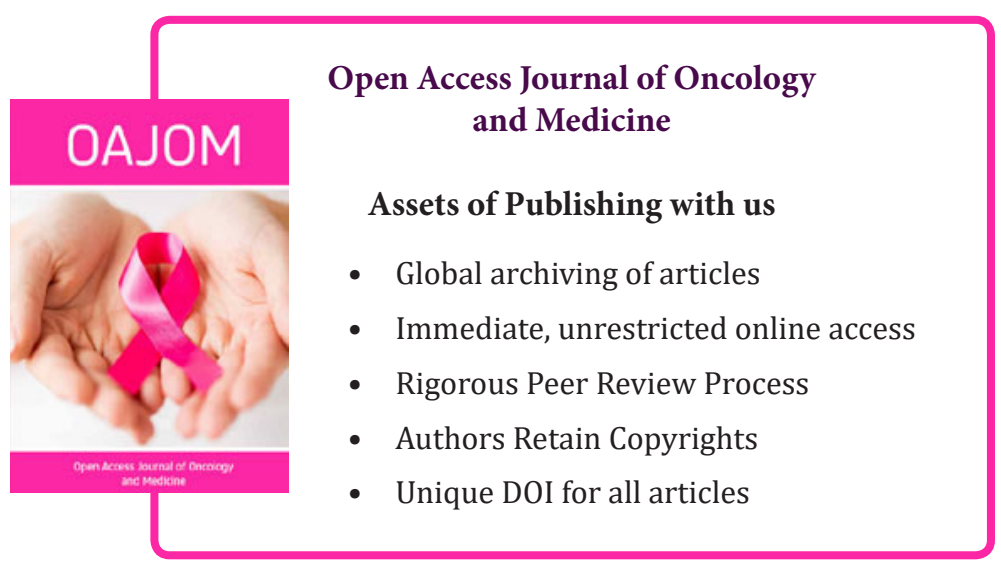

